Submitted to "The International Journal of Biochemistry \& Cell Biology", $11^{\text {th }}$ May 2011, Revised 9th September, 2011, accepted 15 th September, 2011.

\title{
Proteomics reveals a switch in CDK1-associated proteins upon M-phase exit during the Xenopus laevis oocyte to embryo transition
}

Gaëlle Marteil ${ }^{1,2}$, Jean-Philippe Gagné3, Ewa Borsuk ${ }^{4}$, Laurent Richard-Parpaillon ${ }^{1,2}$, Guy G. Poirier ${ }^{3}$ \& Jacek Z. Kubiak ${ }^{1,2}$

${ }^{1}$ CNRS, UMR 6061, Institute of Genetics and Development of Rennes, Cell Cycle Group, F-35043 Rennes, France.

${ }^{2}$ University Rennes 1, UEB, IFR 140, Faculty of Medicine, F-35043 Rennes, France.

3 Axe cancer, CHUQ Research Center, Faculty of Medicine, Laval University, 2705 Boulevard Laurier, Québec, Canada, G1V 4G2.

${ }^{4}$ Department of Embryology, Institute of Zoology, Faculty of Biology, University of Warsaw, Warsaw, Poland.

\section{A B S T R A C T}

Cyclin-Dependent Kinase 1 (CDK1) is a major M-phase kinase which requires the binding to a regulatory protein, Cyclin $\mathrm{B}$, to be active. CDK1/Cyclin $\mathrm{B}$ complex is called M-phase Promoting Factor (MPF) for its key role in controlling both meiotic and mitotic M-phase of the cell cycle. CDK1 inactivation is necessary for oocyte activation and initiation of embryo development. This complex process requires both Cyclin B polyubiquitination and proteosomal degradation via the ubiquitin-conjugation pathway, followed by the dephosphorylation of the monomeric CDK1 on Thr161. Previous proteomic analyses revealed a number of CDK1-associated proteins in human HeLa cells. It is, however, unknown 
whether specific partners are involved in CDK1 inactivation upon M-phase exit. To better understand CDK1 regulation during MII-arrest and oocyte activation, we immunoprecipitated (IPed) CDK1 together with its associated proteins from M-phase-arrested and M-phaseexiting Xenopus laevis oocytes. A mass spectrometry (MS) analysis revealed a number of new putative CDK1 partners. Most importantly, the composition of the CDK1-associated complex changed rapidly during M-phase exit. Additionally, an analysis of CDK1 complexes precipitated with beads covered with $\mathrm{p} 9$ protein, a fission yeast $s u c 1$ homologue well known for its high affinity for CDKs, was performed to identify the most abundant proteins associated with CDK1. The screen was auto-validated by identification of: i) two forms of CDK1: Cdc2A and B, ii) a set of cyclins B with clearly diminishing number of peptides identified upon M-phase exit, iii) a number of known CDK1 substrates (e.g. peroxiredoxine) and partners (e.g. HSPA8, a member of the HSP70 family) both in IP and in p9 precipitated pellets. In IP samples we also identified chaperones, which can modulate CDK1 threedimensional structure, as well as calcineurin, a protein necessary for successful oocyte activation. These results shed a new light on CDK1 regulation via a dynamic change in the composition of the protein complex upon M-phase exit and the oocyte to embryo transition.

\section{Introduction}

MPF (M-phase Promoting Factor) is the universal molecular regulator of M-phase progression (Masui and Markert, 1971). Identification of the molecular nature of MPF was possible due to the appropriateness Xenopus laevis oocytes appropriateness for biochemical analysis. MPF is composed of a kinase, CDK1 (Cyclin-Dependent Kinase 1), and a regulatory subunit, Cyclin B (Gautier et al., 1988; Lohka et al., 1988). CDK1/Cyclin B is associated with a third component of the complex, the p9 protein (Xe-p9 in Xenopus, Cks1 and Cks2 in mammals, orthologues of fission yeast Suc1 protein; van Zon et al. 2010.). The activation of CDK1 triggers M-phase entry, whereas its inactivation is linked to M-phase exit (Labbe et al., 1989; Riabowol et al., 1989). In Xenopus, CDK1 is activated during oocyte maturation and inactivated upon fertilization triggering embryo development. The sperm entry or a parthenogenetic treatment trigger an increase in intracellular free $\mathrm{Ca}^{2+}$ concentration promoting CDK1 inactivation that allows MII exit and the beginning of embryo development. This inactivation is due to the dissociation of CDK1/Cyclin B complex, Cyclin B degradation and CDK1 Thr-161 dephosphorylation (Nishiyama et al., 2000; Chesnel et al., 2006; Chesnel et al., 2007). More precisely, the APC/C (Anaphase-Promoting Complex/Cyclosome)- 
dependent polyubiquitination of cyclin B targets the fully active CDK1/Cyclin B complex to the $26 \mathrm{~S}$ proteasome. The $19 \mathrm{~S}$ regulatory particle of the proteasome unfolds and dissociates Cyclin B from CDK1 (Nishiyama et al., 2000; Chesnel et al., 2006). Cyclin B dissociation is the earliest and indispensable step of CDK1 inactivation. Once separated from CDK1, Cyclin B is degraded, whereas the kinase is dephosphorylated on Thr-161 by type 2C protein phosphatase (Chesnel et al., 2007). Both CDK1 Thr-161 dephosphorylation and Cyclin B degradation ensure the irreversibility of CDK1 inactivation. CDK1 inactivation requires its Tloop refolding, which closes the access of the kinase enzymatic active site. This closure may be mediated by chaperones, assuring the rapidity of CDK1 inactivation (reviewed in Kubiak and El Dika, 2011). Thus CDK1 inactivation may require modifications in association with different partners.

The increasing knowledge on CDK1 makes the hypothesis of a role of CDK1-specific inhibitors and/or chaperones in CDK1 inactivation very attractive. In mammals, two types of CDK inhibitors (CKIs) have been described (for review see De Clercq and Inze, 2006). The Ink4 family inhibits CDK4 and CDK6 by binding to CDK instead of Cyclin (McConnell et al., 1999; Parry et al., 1999), while Cip/Kip family members bind to and inhibit CDK/Cyclin complexes (Chen et al., 1995). In Saccharomyces cerevisiae, Cdc6 in cooperation with Sic1 and Hct1 were postulated to participate in timely Cdc28 (CDK1-homologue) inhibition (Calzada et al., 2001). This function has been recently suggested by Yim and Erikson (2011) in HeLa cells, but has never been shown in developmentally-regulated processes or in Xenopus. However, the CDK1 inhibitory role of Cdc6 remains controversial even in yeast (Archambault et al., 2003). No other CKI has ever been shown to regulate mitotic CDK1 activity, and we wondered whether such regulators could exist during M-phase and participate in the regulation of CDK1 regulation in Xenopus.

Our goal in the present study was to identify CDK1 interactors during M-phase-arrest and upon oocyte activation leading to the entry into the first embryonic interphase. For several reasons, this transition in Xenopus laevis oocytes provides a unique opportunity for the biochemical study of putative changes in the composition of the CDK1 complex. First, the transition from active to inactive CDK1 is easily inducible and highly synchronous. Second, Xenopus laevis oocyte cytoplasm is abundant and rich in proteins (Nishiyama et al., 2000; Chesnel et al., 2006; Chesnel et al., 2007). The feasibility of proteomic analysis of such oocytes and embryos was already demonstrated by our previous MS study of ubiquitinated $X$. laevis proteins (Bazile et al. 2008). Our results show that the composition of the CDK1 complex is indeed modified during CDK1 inactivation and consequently these data open new 
avenues for studying the function of so far unknown protein associations with this major Mphase regulator.

\section{Materials and Methods}

\subsection{Egg collection and activation}

Xenopus laevis females were purchased from NASCO (Fort Atkinson, WI). Females were subcutaneously injected with human chorionic gonadotropin (hCG, 500 IU/female). Unfertilized eggs (UFEs) were collected and washed with F1 buffer (31.25 mM NaCl, 1.75 $\mathrm{mM} \mathrm{KCl}, 60 \mu \mathrm{M} \mathrm{MgCl}_{2}, 2 \mathrm{mM} \mathrm{NaHCO}{ }_{3}, 10 \mathrm{mM}$ Hepes, $0.25 \mathrm{mM} \mathrm{CaCl}_{2}, \mathrm{pH}$ 7.6). UFEs were dejellied with $2 \%$ L-cysteine in F1 buffer, $\mathrm{pH}$ 7.8. Aliquots of 200 UFEs for both CDK1 IP and p9 precipitation and of 20 UFEs for Western blotting analysis were made and frozen in liquid nitrogen. Eggs were activated using $0.5 \mu \mathrm{g} / \mathrm{mL}$ calcium ionophore A23187 for $90 \mathrm{sec}$. Aliquots of 200 activated UFEs were taken out about 7 min after ionophore treatment for both CDK1 IP and p9 precipitation, and aliquots of 20 eggs were taken out 3, 7, 9, 15 and 30 min after treatment for Western blotting analysis.

\subsection{Samples preparation for Western blotting}

Eggs were homogenized in MPF-stabilizing buffer $(80 \mathrm{mM} \beta$-glycerophosphate, $50 \mathrm{mM} \mathrm{NaF}$, $20 \mathrm{mM}$ EGTA, $20 \mathrm{mM}$ Hepes, $15 \mathrm{mM} \mathrm{MgCl}_{2}, 1 \mathrm{mM}$ DTT, $\mathrm{pH}$ 7.5) with mixture of protease inhibitors (1mM AEBSF and $10 \mu \mathrm{g} / \mathrm{mL}$ of aprotinin, leupeptin, pepstatin) and $10 \mu \mathrm{g} / \mathrm{mL}$ of sodium orthovanadate and centrifuged $\left(10000 \mathrm{~g}, 15 \mathrm{~min}, 4^{\circ} \mathrm{C}\right)$. The egg extract was mixed with Laemmli buffer (Laemmli, 1970), heated at $85^{\circ} \mathrm{C}$ and stored at $-20^{\circ} \mathrm{C}$.

\subsection{CDK1 immunoprecipitation}

To IP CDK1 during M-phase and M-phase exit, we used protein extracts of unfertilized (200 UFE) and activated eggs (200 eggs at 7 min post activation). Affi-Prep protein A beads were washed three times with TBS-Triton X100 (50mM Tris- $\mathrm{HCl}, 150 \mathrm{mM} \mathrm{NaCl}, 0.01 \%$ Triton $\mathrm{X} 100, \mathrm{pH}$ 7.5). The beads were then pre-equilibrated with or without (for IP negative control and for pre-clearing step) rabbit polyclonal antibody raised against $X 7 \mathrm{CDK} 1 \mathrm{C}$-terminal peptide (a gift from T. Lorca, CRBM, Montpellier, France), overnight at $4{ }^{\circ} \mathrm{C}$ in TBS-Triton 
X100 (50mM Tris-HCl, $150 \mathrm{mM} \mathrm{NaCl,} \mathrm{0.01 \%} \mathrm{Triton} \mathrm{X100,} \mathrm{pH} \mathrm{7.5),} \mathrm{supplemented} \mathrm{with}$ proteases inhibitors and sodium orthovanadate (as above). We selected this antibody because it was previously successfully used to specifically immunoprecipitate CDK1 from $X$. laevis oocytes (Krasinska et al. 2008). Fifteen hours later, aliquots of 200 eggs were homogenized in $1 \mathrm{~mL}$ of immunoprecipitation buffer $(20 \mathrm{mM}$ Tris- $\mathrm{HCl}, \mathrm{pH} 7.5,150 \mathrm{mM} \mathrm{NaCl}, 10 \%$ glycerol, $2 \mathrm{mM}$ EDTA, $50 \mathrm{mM} \mathrm{NaF}, 50 \mathrm{mM} \beta$-glycerophosphate, $0.2 \% \mathrm{NP}-40$ ) and centrifuged at $10000 \mathrm{~g}$ for $15 \mathrm{~min}$ at $4^{\circ} \mathrm{C}$. Protein extracts were centrifuged again at $10000 \mathrm{~g}$ for $15 \mathrm{~min}$ at $4^{\circ} \mathrm{C}$. Volumes of protein extracts were adjusted to $2 \mathrm{~mL}$ with IP buffer containing protease inhibitors, and a $15 \mu 1$ aliquot was collected for Western blotting analysis ("total fraction"). After three brief washes with IP buffer, naked beads $(200 \mu \mathrm{L}$ per protein extract) were incubated with protein extracts and the mixture was agitated for 2 hours at $4{ }^{\circ} \mathrm{C}$ to pre-clear the extract. The mixture of naked beads and egg extracts was then centrifuged at $4000 \mathrm{rpm}, 3$ min, $4^{\circ} \mathrm{C}$. The supernatants were mixed with $100 \mu \mathrm{L}$ of naked beads (IP negative control) or of Affi-Prep protein A beads cross linked to CDK1 antibodies (dimethyl pimelimidate dihydrochloride was used as cross linking agent) previously washed twice with homogenizing buffer and agitated for 2.5 hours at $4^{\circ} \mathrm{C}$. After centrifugation $\left(1300 \mathrm{~g}, 3 \mathrm{~min}, 4^{\circ} \mathrm{C}\right)$, the supernatants were kept for a second round of IP, but an aliquot of $15 \mu \mathrm{L}$ for each supernatant was conserved for Western blotting analysis ("unbound fraction"). The pellets were washed three times with $1.5 \mathrm{~mL}$ of TBS-Triton X100 with protease inhibitors. Proteins were eluted from beads using $100 \mu \mathrm{L}$ of $100 \mathrm{mM}$ glycine, $\mathrm{pH} 2.0$. The eluted proteins were frozen at $-20^{\circ} \mathrm{C}$ and the beads were eluted a second time with glycine and washed three times with TBSTriton X100 and two times with IP buffer. The additional round of IP was performed as previously described by incubating the supernatant of the first round with the beads. The two aliquots of eluted proteins were pooled and neutralized with $1 \mathrm{M}$ Tris-HCl, pH 9.2. Laemmli buffer was added and the samples were heated at $85^{\circ} \mathrm{C}$ for $5 \mathrm{~min}$. A small aliquot was retained for Western blot analysis (bound fraction) and the remaining was analyzed by mass spectrometry.

\subsection{CDK1 precipitation with $p 9$ beads}

To precipitate CDK1 with p9 beads during M-phase and M-phase exit, we used protein extracts made from unfertilized (200 UFE) and activated eggs (200 eggs taken out 7 min. after activation). p9-Sepharose beads were a kind gift from L. Meijer and O. Lozach (Marine Station, Roscoff, France; Vogel et al. 2002). p9-bound beads and naked Sepharose beads for 
pre-clearing were pre-equilibrated overnight at $4{ }^{\circ} \mathrm{C}$ in homogenizing buffer $(25 \mathrm{mM}$ MOPS, pH 7.2, 60mM $\beta$-glycerophosphate, $15 \mathrm{mM}$ EGTA, $15 \mathrm{mM} \mathrm{MgCl}_{2}, 2 \mathrm{mM}$ DTT, $1 \mathrm{mM} \mathrm{NaF}$, $1 \mathrm{mM}$ sodium orthovanadate) with protease inhibitors and 1\% BSA. Aliquots of 200 eggs were homogenized in $0.8 \mathrm{~mL}$ of homogenizing buffer and centrifuged at $10000 \mathrm{~g}$ for $15 \mathrm{~min}$ at $4^{\circ} \mathrm{C}$. Protein extracts were centrifuged at $10000 \mathrm{~g}$ for $15 \mathrm{~min}$ at $4^{\circ} \mathrm{C}$. Volumes of protein extracts were adjusted to $1.5 \mathrm{~mL}$ with homogenizing buffer including protease inhibitors and a $20 \mu \mathrm{l}$ aliquot was collected for Western blotting ("total fraction"). Naked Sepharose beads $(200 \mu \mathrm{L}$ per protein extract) were incubated with protein extracts and agitated for 2 hours at $4^{\circ} \mathrm{C}$. After centrifugation $\left(1300 \mathrm{~g}, 3 \mathrm{~min}, 4^{\circ} \mathrm{C}\right)$, supernatants were mixed to $200 \mu \mathrm{L}$ of $\mathrm{p} 9$ beads or naked beads (negative control) and agitated for 2.5 hours at $4^{\circ} \mathrm{C}$. After centrifugation $\left(1300 \mathrm{~g}, 3 \mathrm{~min}, 4^{\circ} \mathrm{C}\right)$, the supernatants $(30 \mu \mathrm{L})$ were collected for Western blotting ("unbound fraction") and the pellets of $\mathrm{p} 9$ beads were washed four times with $5 \mathrm{~mL}$ of washing buffer (Tris- $\mathrm{HCl} \mathrm{pH}$ 7.4, 5mM NaF, $250 \mathrm{mM} \mathrm{NaCl}, 5 \mathrm{mM}$ EDTA, 5mM EGTA, 0.1\% Nonidet P-40) with protease inhibitors. The proteins were eluted with $150 \mu \mathrm{L}$ of Laemmli buffer and heated at $85^{\circ} \mathrm{C}$ for $5 \mathrm{~min}$.

\subsection{Immunoblotting}

Proteins were separated by $12 \%$ SDS-PAGE and transferred to Hybond C membranes (GE Healthcare). Membranes were probed with antibodies to: CDK1 (mouse monoclonal, MS110-PO, Interchim), Cyclin B2 (gift from T. Lorca, CRBM, Montpellier, France; rabbit polyclonal) and MCM4 (both gifts from M. Méchali, IGH, Montpellier, France, rabbit polyclonal).

\subsection{Sample preparation for mass spectrometry analysis}

Eluted proteins were resolved on a $4-12 \%$ Criterion $^{\mathrm{TM}}$ XT Bis-Tris gradient gel (Bio-Rad), and stained with SYPRO Ruby (Bio-Rad). Images were acquired on a Geliance CCD-based bioimaging system (PerkinElmer).

\subsection{LC-MS/MS analysis}

The entire protein profile of each lane on SDS-PAGE was sliced from the gel into 16 bands using a gel excision Lanepicker ${ }^{\mathrm{TM}}$ (The Gel Company). Gel slices were deposited into 96-well 
plates. In-gel protein digestion was performed by a MassPrep ${ }^{\mathrm{TM}}$ liquid handling station (Micromass), using sequencing-grade modified trypsin (Promega). Peptide extracts were dried using a SpeedVac ${ }^{\mathrm{TM}}$. Peptide extracts were separated by online reversed-phase (RP) nanoscale capillary liquid chromatography (nanoLC) and analyzed by ES MS/MS. Analyses were performed on a Thermo Surveyor MS pump connected to an LTQ linear ion trap mass spectrometer (Thermo Electron, San Jose, CA) equipped with a nanoelectrospray ion source (Thermo Electron, San Jose, CA). Peptide separation took place within a PicoFrit column BioBasic C18, $10 \mathrm{~cm} \times 0.075 \mathrm{~mm}$ internal diameter (New Objective, Woburn, MA) with a linear gradient from 2 to $50 \%$ solvent B (acetonitrile, $0.1 \%$ formic acid) in $30 \mathrm{~min}$, at 200 $\mathrm{nL} / \mathrm{min}$. Mass spectra were acquired using data dependent acquisition mode (Xcalibur software, version 2.0). Each full-scan mass spectrum (400 to $2000 \mathrm{~m} / \mathrm{z}$ ) was followed by collision-induced dissociation of the seven most intense ions. The dynamic exclusion function was enabled (30 s exclusion), and the relative collisional fragmentation energy was set to $35 \%$.

\subsection{Interpretation of Tandem-MS Spectra}

The RAW files generated from MS/MS spectra were uploaded to the MASCOT search engine (Matrix Science, London, UK; version 2.2.0) for protein identifications. The parameters for database searching were as follows: (I) Protein database: Uniref_100, (II) Taxonomy: Xenopus laevis [TaxID: 8355, 15599 entries], (III) Trypsin digestion with up to two missed cleavage sites, (IV) Fragment and parent ion mass tolerance were $0.5 \mathrm{Da}$ and $2.0 \mathrm{Da}$ respectively, (V) Iodoacetamide derivative of cysteine as a fixed modification and oxidation of methionine as a variable modification.

\subsection{Criteria for protein identification}

Scaffold (version 03_00_01, Proteome Software Inc., Portland, OR) was used to validate MS/MS based peptide and protein identifications, and to provide confidence level (\% probability) of the identification. Peptide identifications were accepted if they could be established at greater than $95.0 \%$ probability by the PeptideProphet algorithm (Keller et al., 2002). Protein identifications were accepted if they could be established at greater than $95.0 \%$ probability and contained at least 2 distinct peptides. Protein probabilities were assigned by the ProteinProphet algorithm (Nesvizhskii et al., 2003). Proteins containing similar peptides 
that could not be differentiated based on MS/MS analysis alone were grouped to satisfy the principles of parsimony. A Scaffold 3 report is provided as Supporting Information. This file can be accessed with a free viewer available from Proteome Software, Inc. website (http://www.proteomesoftware.com). This file contains all the spectral information, including the accession number for each protein sequence, Mascot scores, protein sequence coverage and amino acid residues modifications, statistical probability modeling, and spectral counting.

\section{Results}

We have applied two different affinity-based approaches to identify proteins bound to CDK1. The first approach is a classical CDK1 pull-down using an anti-CDK1 antibody (Krasinska et al. 2008), whereas the second is based on CDK1 precipitation via p9 beads (Patra and Dunphy, 1996). MS analysis was used to identify CDK1-associated proteins in M-phase, when the kinase is fully active, and during its inactivation upon M-phase exit. Experiments were repeated several times to establish the method. Below, we present data from single experiments obtained using IP and p9 purifications according to the final satisfactory procedure described in Materials \& Methods section. Scaffold software was used to merge the identifications, validate the peptides and proteins hits and discriminate homologous proteins (150 unique proteins, 8866 spectra, $0.1 \%$ protein false discovery rate (FDR), see Supplementary file Protein IDs. SF3)

\subsection{CDK1 immunoprecipitation}

As shown in Fig. 1a, the protein markers (Mcm4 and cyclin B2) confirm MII exit. CDK1 immunoprecipitations were performed on extracts from MII-arrested eggs (T0) and activated eggs (7 minutes after activation, T7). A negative IP control with naked beads instead of antiCDK1-coupled beads was performed. To assess the yield during the stages of purification, aliquots of total egg extract (total), unbound fraction (unbound) and proteins bound to the beads (bound) were taken for Western blot analysis. CDK1 was almost completely depleted from extracts (compare unbound and bound fractions from IP T0 and T7 in Fig. 1B). To verify if this approach also enables CDK1-interacting proteins to be precipitated, we assessed the presence of Cyclin B2. As expected, Cyclin B2 was also depleted and found in beadbound fractions. We observed a clear decrease in cyclin B2 abundance between T0 and T7 extracts, confirming activation of eggs. No signal for CDK1 and Cyclin B2 was found in 
negative-control bound fractions, indicating that protein interactions were specific. These results showed that both $\mathrm{CDK} 1$ and $\mathrm{CDK} 1$-associated proteins were efficiently depleted.

SYPRO Ruby-stained gel containing all four bound fractions (M-phase, M-phase exit and their respective negative controls) showed quantitative and qualitative differences (Fig. 1C). Control samples contained much less protein than immunoprecipitation samples, indicating that proteins interacting with $\mathrm{CDK} 1$ are abundant and that only few proteins interact nonspecifically with naked beads. Differences between bound fractions of M-phasearrested and activated extracts were also visible, suggesting that partners of CDK1 change upon M-phase exit. To identify CDK1 partners, protein bands corresponding to the entire gel were excised and analyzed by LC-MS/MS. We identified 30 proteins during M-phase (Table 1) and 42 during M-phase exit (Table 2). A total of 23 proteins were common to both samples. As expected, the major biological process that stands out for CDK1-associated proteins is cell cycle progression (Fig. 2). A few other purified proteins are involved in DNA/RNA metabolism, cytoskeleton/vesicle transport, fertilization for the M-phase sample. Most importantly for the validity of the analysis, the two isoforms of CDK1, Cdc2-A and Cdc2-B, were identified in both samples. Moreover, among the 21 proteins common to both samples, four are involved in cell division, and two, Cyclins B2 and B4, are known regulatory subunits of CDK1. The two other cell cycle proteins common for M-phase and M-phase exit samples, are ERK2 (mitogen activated protein kinase 1) and calcineurin A (a serine/threonine protein phosphatase). Another category of proteins shared between M-phase and M-phase exit are chaperones belonging to T-complex protein1 (Tcp1) family and heat-shock proteins (A8 and D1).

Among proteins specifically interacting with M-phase CDK1, three are egg envelope components (X1ZPA, egg envelope glycoprotein and component ZPAX). M-phase exitspecific CDK1-interactors are mainly involved in metabolism (7 out of 19) and this group apparently increases upon CDK1 inactivation. Among them, two are involved in proteolysis (arginyl aminopeptidase and LOC431925 protein). Interestingly, Septin 9 found in this group is potentially involved in late mitosis and cytokinesis (Bi et al., 1998; Cao et al., 2009; Nguyen et al., 2000; Spiliotis et al., 2005). The other proteins found exclusively during Mphase exit are involved in protein folding (a member of Tcp1 family), cytoskeleton/vesicle transport (2 proteins), DNA/RNA metabolism (2 proteins) and other functions (5 proteins). As expected, fertilization-specific proteins were missing in CDK1 complexes following oocyte activation. 


\subsection{Affinity purification with $p$ 9-beads}

As shown in Fig. 3A, protein markers confirmed egg activation. As in CDK1 IP, p9 precipitation was performed on extracts from MII (T0) eggs, and eggs 7 min after activation (T7). CDK1 was almost completely depleted from egg extracts (compare unbound and bound fractions from p9 T0 and T7 in Fig. 3B). We also searched for Cyclin B2 in the different fractions to test whether this method allows co-precipitation of CDK1 partners. As expected, Cyclin B2 was depleted from the extract, and was found in the bound fraction of the T0 extract. We did not detect Cyclin B2 in the bound fraction of the T7 extract, due to its almost complete degradation at this time point. No signals for CDK1 and Cyclin B2 were detected in the negative control bound fractions, indicating that protein interactions were specific. These results showed that $\mathrm{p} 9$ precipitation depleted both $\mathrm{CDK} 1$ and its associated proteins.

The staining of the gel containing all four bound fractions showed fewer differences between samples than in IP experiments (Figs. 1C and 3C). Nineteen proteins were identified during M-phase (Table 3) and 37 during M-phase exit (Table 4). Sixteen proteins were common for the two samples. As in IP, p9 precipitation allowed us to identify more proteins in activated oocytes compared to MII-arrested ones (Fig. 3C). A functional classification indicates that the proteins identified are mainly involved in cell cycle, folding (heat shock proteins $70 \mathrm{kDa}$ ), metabolism (L-isoaspartate O-methyltransferase and X1Gst) and DNA/RNA metabolism (Nif3-like protein 1, Ribosomal protein S30, Double-stranded RNA-binding protein A). Remaining proteins are involved in cytoskeleton/vesicle transport (Cofilin-1-A) and other functions (Traf2 and Nck-interacting protein kinase, Peroxiredoxin-2, GalectinVIIa). As expected, p9 beads precipitated two isoforms of CDK1, Cdc2-A and Cdc2-B, next to CDK2 (represented by a single peptide, indicating a low amount; see Tables 3 and 4) in both samples showing that other identified proteins may be partners of either Cdc2-A or Cdc2-B subunit, and/or of CDK2. Identification of Cyclins B2 and B4 confirmed the presence of CDK1-associated proteins in p9 samples. Concerning specific M-phase proteins in p9precipitates, two are B-type Cyclins (B1 and B5) and one is involved in cell adhesion (Junction plakoglobin). Proteins specific for M-phase exit (Table 4) are mainly involved in metabolism (6 out of 21), DNA/RNA metabolism (6 proteins), protein folding (3), and other functions (6).

\subsection{Comparative analysis of the two approaches}


Among all proteins co-purified with CDK1 and identified by these two approaches, six were common for all samples: Cdc2A, Cdc2B, Cyclin B2, Cyclin B4, Peroxiredoxin-2 and Heat shock protein A8 (Fig. 5). The presence of two CDK1 isoforms and two B-type Cyclins (B2 and B4) in all samples confirms that CDK1 partners could indeed be present among other identified proteins. None of the proteins was exclusively present in M-phase samples, whereas two proteins involved in metabolism were specific for M-phase exit samples: pyruvate kinase and the $\alpha$ subunit of ATP synthase (Fig. 5). The presence of pyruvate kinase and the $\alpha$ subunit of ATP synthase in M-phase exit samples obtained by two methods argue for their real association with CDK1.

\section{Discussion}

\subsection{Validation of the proteomic screen}

Our mass spectrometry analysis of CDK1 co-IPed proteins was supplemented by analysis of p9-precipitates. Large-scale proteomic screens often give rise to false-positive interactions (e.g. Trinkle-Mulcahy et al. 2008). The analysis of p9-precipitated proteins focused on verification of major CDK1 partners found by IP, as p9 beads also precipitate p9-specific partners, which may not be associated with either CDK1 or CDK2. Despite this shortcoming that makes the $\mathrm{p} 9$ precipitation less stringent for CDK1 partners than CDK1 IP, p9-beads are widely used to precipitate CDK1 in Xenopus oocytes, for instance to measure CDK1 activity (Patra and Dunphy, 1996). In both cases two CDK1 isoforms, Cdc2-A and Cdc2-B, and CDK1 partners, cyclins B2 and B4, were identified. CDK1 was used as a positive control in a proteomic screen using HeLa cells and cyclins B were also identified as CDK1 interactors as expected (Fig. S5(B) in Hutchins at al. 2010; www.mitocheck.org ). In addition, in our screen the number of identified peptides of two cyclins B diminished in M-phase exit samples concomitant with their advanced degradation. The successful identification of remaining Cyclins B2 and B4 in activated oocytes (both with IP and p9 precipitation) demonstrates the relative sensitivity of the method used here to purify CDK1 protein complexes. These data auto-validated our screen and confirmed that we efficiently co-IPed partners of CDK1 (Cdc2A or Cdc2-B) complexes. The absence of CDK2, the closest CDK to CDK1 in oocytes, in the IP further confirmed the specificity of this method. Thus the combination of methods used was appropriate for the purification of complexes containing CDK1 in both states: fully active and being inactivated CDK1 complex purification. 
Among other identified proteins only two were common for all samples (Peroxiredoxin-2 and Heat shock protein A8) and two (pyruvate kinase and the $\alpha$ subunit of ATP synthase) specific for M-phase exit samples and detected by both approaches. All these proteins were found often as contaminants in other proteomic analyses (Trinkle-Mulcahy et al. 2008). However, the absence of these proteins in our control argues for their true association with CDK1 (see Tables 1-4). As p9 precipitation is a method that enables the purification of CDK1, CDK2 and p9 partners, specific interactors of CDK1 are diluted among all co-precipitated proteins. As a consequence, their identification by mass spectrometry analysis could be impaired explaining why the number of overlapping proteins between the two methods is low. Another explanation could rely on differences in experimental conditions, more stringent for $\mathrm{p} 9$ precipitations than for IP, decreasing the number of proteins purified on p9 beads. Nevertheless, we managed to identify molecules engaged in CDK1 complexes at two studied states of activity and the major components common for the two methods.

\section{2. CDK1 partners specifically present during M-phase exit}

Our proteomic analysis revealed the presence of two proteins specifically detected during Mphase exit: pyruvate kinase and the $\alpha$ subunit of ATP synthase, both involved in cellular energy metabolism. Pyruvate kinase PKM2 was also identified as a CDK1 partner in human cells, but without indication of a potential cell cycle-dependent association (Hutchins et al. 2010; www.mitocheck.org). An interaction between CDK1 and the $\alpha$ subunit of ATP synthase has never been demonstrated and its significance remains unclear considering their functions and subcellular localization. Pyruvate kinase and ATP synthase could associate with inactive CDK1 or could be attached to a common support fixing CDK1 during its inactivation for example on cytoskeletal elements, as CDK1 associates with the spindle and its inactivation requires a functional spindle (Kubiak et al. 1993; Thibier et al. 1997). The association between CDK1 and metabolic enzymes involved in cell cycle progression is an attractive hypothesis. For instance, 6-phosphofructo-2-kinase (PFKFB3) and fructose 2,6bisphosphate activate CDK1 to phosphorylate p27 in HeLa lysates, indicating that these proteins may have direct allosteric effects activating CDK1 (Yalcin et al. 2009). The link between ATP cycle and CDK1 inactivation is also obvious in the light of the requirement of ATP for cyclin B polyubiquitination and M-phase exit (Miniowitz-Shemtov et al. 2010). 
Interestingly, Hutchins and collaborators (2010) also found, besides pyruvate kinase, a number of metabolic enzymes associated with CDK1 in HeLa cells (e.g. carbonic anhydrase CA2, carbamoyl-phosphate synthase 1 CPS1, tRNA (cytosine-5-)-methyltransferase NSUN2, phosphoglycerate kinase 1 PGK1, 3-phosphoglycerate dehydrogenase PHGDH, thymidine phosphorylase TYMP; www.mitocheck.org).

Among potential CDK1 partners specifically present during M-phase exit following CDK1 IP, two are known to be involved in cytoskeleton functions: dynein, the microtubule motor protein (Burakov and Nadezhdina, 2006) and septin 9, a GTP binding protein involved in microtubule and actin function (Cao et al., 2009). This is also in agreement with results obtained by Hutchins and colleagues (2010), who identified a number of cytoskeletal proteins associated with human CDK1 (e.g. ezrin EZR, actin-related protein 3 homolog ACTR3, actin binding protein coronin CORO1C, dynactin 1 DCTN1, Cytoplasmic dynein 1 heavy chain 1 DYNC1H1, non-erythrocytic spectrin SPTBN2; www.mitocheck.org). CDK1/cyclin B is localized on the spindle in mitosis and meiosis, where it regulates spindle formation and maintenance (Brunet and Maro, 2005; Huo et al., 2005; Nakamura et al., 2005). Moreover, an intact spindle is necessary for cyclin B degradation and CDK1 inactivation (Kubiak et al. 1993; Thibier et al. 1997). Thus, interactions between CDK1 and microtubule-interacting proteins seem of great importance for spindle maintenance and for correct localization of CDK1 own residual activity. The presence of actin-related proteins both in our screen and by Hutchins et al. (2010) argues the need for a serious analysis of CDK1-actin cytoskeleton interactions.

\subsection{CDK1 partners common for M phase and M-phase exit}

Among common putative partners of CDK1 identified by our two approaches, the molecular chaperone HspA8, a member of Hsp70 family, seems to be particularly interesting. Hsp70 colocalizes with CDK1 on the meiotic spindle of sea urchin oocytes (Geraci et al., 2003). A member of the Hsp70 family (Hsp70-2) is a molecular chaperone of CDK1 involved in CDK1/cyclin B1 complex formation, and essential for the cell cycle in spermatogenesis (Dix et al., 1996; Zhu et al., 1997). Interestingly, we did not find any members of the Hsp90 family, known as Mos-specific chaperone in Xenopus laevis oocytes (Fisher et al. 2000). Taken together, these results show a clear molecular link between the Hsp70 family and CDK1, confirmed by our proteomic screen. 
The other common protein for all samples is Peroxiredoxin-2, a protein involved in cell redox homeostasis (Hofmann et al., 2002). Two members of Peroxiredoxin family (Prx family) including Prx-2 are phosphorylated in vitro by CDK1 (Chang et al., 2002). In vivo phosphorylation of Prx-1 on Thr90 occurs only during mitosis when CDK1 is active. A proteomic screen performed in bovine oocytes also revealed that Prx-2 is phosphorylated during oocyte maturation via CDK1 or MAPK (Bhojwani et al., 2006). CDK1-mediated phosphorylation at Thr90 of Prx-1 leads to decrease of its activity (Chang et al., 2002). The significance of Prx-1 inactivation and consequently of $\mathrm{H}_{2} \mathrm{O}_{2}$ increase on the M-phase progression remains unclear. However, one putative target of $\mathrm{H}_{2} \mathrm{O}_{2}$ could be the $\mathrm{Cdc} 25 \mathrm{C}$ phosphatase, a major CDK1 activator (Morgan, 1995; Perdiguero and Nebreda, 2004; Wang et al., 2007). Cdc25C activity requires reducing agents, and oxidative stress induces its degradation (Savitsky and Finkel, 2002). The CDK1-Prx-2 interaction suggested by our screen could lead to CDK1-dependent inhibitory phosphorylation of Prx-2, and consequently an increase in $\mathrm{H}_{2} \mathrm{O}_{2}$ concentration. This oxidative stress could participate in $\mathrm{Cdc} 25 \mathrm{C}$ inactivation, and in turn CDK1 inactivation. As peroxiredoxins often appear often as contaminants in proteomic screens (Trinkle-Mulcahy et al. 2008), the potential association between Prx-2 and CDK1 will have to be carefully examined.

Among common potential CDK1 partners during M-phase and M-phase exit in both methods used in our study, several were involved in cytoskeletal functions. In the IP experiments kinectin, a membrane anchor for kinesin (Kumar et al., 1995), was especially abundant. Copin, a calcium-dependent membrane binding protein involved in membrane trafficking (Creutz et al., 1998) was also identified during M-phase and M-phase exit by IP. On the other hand, cofilin 1-A (Bernstein and Bamburg, 2010) was identified in both p9 samples (Tables 3 and 4). A member of cofilin family was already reported as a substrate of CDK1 and its phosphorylation is involved in the functionality of inositol $(1,4,5)$-trisphosphate receptors in starfish oocytes (Santella et al., 2003). Copin A knockout in Dictyostelium leads to the formation of multinucleated cells (Damer et al., 2007) and cofilin localizes at the contractile ring, suggesting their involvement in cytokinesis (Nagaoka et al., 1995). Together with the identification of septin 9 during M-phase exit by IP, these results suggest interplay between CDK1 and cytokinesis. Other proteins linking CDK1 and cytoskeleton are members of TCP1 complex family, identified in two IP samples. They are involved in tubulin folding (Brown et al., 1996) and colocalizes with CDK1 at the mitotic spindle in sea urchin embryos (Agueli et al., 2001). All these results suggest that CDK1 is cytoskeleton-anchored. 
Among common putative CDK1 partners during M-phase and M-phase exit present only in IP samples, two are involved in cell cycle regulation: calcineurin A and ERK2. Calcineurin is a highly conserved phosphatase composed of a catalytic subunit, calcineurin A and a regulatory one, calcineurin B (Rusnak and Mertz, 2000). Calcineurin is required for CSF release during MII exit in Xenopus oocytes via dephosphorylation of Apc3 and Cdc20 contributing to APC/C activation and cyclin B2 degradation (Chung and Chen, 2003; Mochida and Hunt, 2007; Nishiyama et al., 2007; Yudkovsky et al., 2000). Calcineurin is also required for completion of meiosis in Drosophila oocytes (Takeo et al., 2010). The association between calcineurin $\mathrm{A}$ and $\mathrm{CDK} 1$ that we found may suggest that these two proteins regulate each other, or are linked by a common support (e.g. the cytoskeleton).

ERK2 MAP kinase is involved in CDK1 activation during oocyte maturation (Castro et al., 2001). The ERK2 pathway catalyzes the inhibitory phosphorylation of Myt1 kinase, responsible for the inhibitory phosphorylation of CDK1 on Thr14 and Tyr 15 (Mueller et al., 1995), and is required for CDK1 activation. ERK2 is also involved in activation of Cdc25C at the G2/M transition (Wang et al., 2007) and Cdc25 is essential for CSF arrest (Lorca et al., 2010). A clear feedback links ERK2 and CDK1 in meiosis (Abrieu et al., 2001), which changes during embryonic mitosis (Bazile et al. 2007). Thus, CDK1 and ERK2 are functionally related especially during meiosis. However, until now no physical association between these proteins has been shown.

\subsection{Different CDK1 complexes with potentially different functions}

Each of two CDK1 isoforms identified in this study (Cdc2-A and B) may be associated with different types of partners. The nature of the cyclin associated with CDK1 is essential for the substrate specificity of CDK1. Upon M-phase exit the timing of cyclin degradation is sequential (Hochegger et al., 2001). Thus, different CDK1 complexes may exert various functions according to the type of cyclin they harbour (Gong and Ferrell, 2010; Kõivomägi et al. 2011). The spectrum of different CDK1 complexes can be enlarged by association with other partners identified in the current study.

\subsection{Conclusions}

In this paper we have shown that CDK1 interacts with different proteins depending on the cell cycle stage (namely upon MII-arrest and oocytes activation). Our results show the 
necessity to study individually CDK1-other proteins associations to fully understand the regulation of this major cell cycle kinase. It also completes information on potential CDK1 associated proteins previously obtained in much larger screen of protein complexes involved in mitotic regulation by Hutchins et al. (2010) in human cells. Our dynamic approach points the necessity to analyse the evolution of protein complexes to better understand cell cycle regulation and especially the mitotic progression.

\section{Acknowledgements}

We are grateful to Laurent Meijer and Olivier Lozach (Roscoff, France) for p9 beads, Thierry Lorca (Montpellier, France) for the gift of a large quantity of precipitating XlCDK1 antibody, Marcel Méchali (Montpellier, France) for MCM4 antibody and James R. Hutchins (Montpellier, France) for valuable discussions and critical reading of the manuscript. The authors were supported by grants from Ligue Contre le Cancer and Association pour la Recherche contre le Cancer to JZK. GM was a recipient of a fellowship from the French Ministère de la Recherche et de l'Enseignement supérieur and MED from the Lebanese Government.

\section{References}

Abrieu, A., Doree, M. and Fisher, D. (2001). The interplay between cyclin-B-Cdc2 kinase (MPF) and MAP kinase during maturation of oocytes. J Cell Sci 114, 257-67.

Agueli, C., Geraci, F., Giudice, G., Chimenti, L., Cascino, D. and Sconzo, G. (2001). A constitutive 70 $\mathrm{kDa}$ heat-shock protein is localized on the fibres of spindles and asters at metaphase in an ATPdependent manner: a new chaperone role is proposed. Biochem J 360, 413-9.

Archambault, V., Li, C. X., Tackett, A. J., Wasch, R., Chait, B. T., Rout, M. P. and Cross, F. R. (2003). Genetic and biochemical evaluation of the importance of Cdc6 in regulating mitotic exit. Mol Biol Cell 14, 4592-604.

Bazile F, Pascal A, Karaiskou A, Chesnel F, Kubiak JZ. (2007). Absence of reciprocal feedback between MPF and ERK2 MAP kinase in mitotic Xenopus laevis embryo cell-free extract. Cell Cycle 6, 489-96.

Bazile F, Gagné JP, Mercier G, Lo KS, Pascal A, Vasilescu J, Figeys D, Poirier GG, Kubiak* JZ, Chesnel F. (2008). Differential Proteomic Screen To Evidence Proteins Ubiquitinated upon Mitotic Exit in Cell-Free Extract of Xenopus laevis Embryos. J Proteome Res. 7(11), 4701-4714.

Bernstein, B. W. and Bamburg, J. R. (2010). ADF/cofilin: a functional node in cell biology. Trends Cell Biol 20, 187-95.

Bhojwani, M., Rudolph, E., Kanitz, W., Zuehlke, H., Schneider, F. and Tomek, W. (2006). Molecular analysis of maturation processes by protein and phosphoprotein profiling during in vitro maturation of bovine oocytes: a proteomic approach. Cloning Stem Cells 8, 259-74.

Bi, E., Maddox, P., Lew, D. J., Salmon, E. D., McMillan, J. N., Yeh, E. and Pringle, J. R. (1998). Involvement of an actomyosin contractile ring in Saccharomyces cerevisiae cytokinesis. $J$ Cell Biol 142, 1301-12. 
Brown, C. R., Doxsey, S. J., Hong-Brown, L. Q., Martin, R. L. and Welch, W. J. (1996). Molecular chaperones and the centrosome. A role for TCP-1 in microtubule nucleation. J Biol Chem 271, 824-32.

Brunet, S. and Maro, B. (2005). Cytoskeleton and cell cycle control during meiotic maturation of the mouse oocyte: integrating time and space. Reproduction 130, 801-11.

Bueno, A and Rusell P. (1992). Dual functions of CDC6: a yeast protein required for DNA replication also inhibits nuclear division. The EMBO J. 11, 2167-76.

Burakov, A. V. and Nadezhdina, E. S. (2006). [Dynein and dynactin as organizers of the system of cell microtubules]. Ontogenez 37, 323-39.

Calzada, A., Sacristan, M., Sanchez, E. and Bueno, A. (2001). Cdc6 cooperates with Sic1 and Hct1 to inactivate mitotic cyclin-dependent kinases. Nature 412, 355-8.

Cao, L., Yu, W., Wu, Y. and Yu, L. (2009). The evolution, complex structures and function of septin proteins. Cell Mol Life Sci 66, 3309-23.

Castro, A., Peter, M., Lorca, T. and Mandart, E. (2001). c-Mos and cyclin B/cdc2 connections during Xenopus oocyte maturation. Biol Cell 93, 15-25.

Chang, T. S., Jeong, W., Choi, S. Y., Yu, S., Kang, S. W. and Rhee, S. G. (2002). Regulation of peroxiredoxin I activity by Cdc2-mediated phosphorylation. J Biol Chem 277, 25370-6.

Chen, J., Jackson, P. K., Kirschner, M. W. and Dutta, A. (1995). Separate domains of p21 involved in the inhibition of Cdk kinase and PCNA. Nature 374, 386-8.

Chesnel, F., Bazile, F., Pascal, A. and Kubiak, J. Z. (2006). Cyclin B dissociation from CDK1 precedes its degradation upon MPF inactivation in mitotic extracts of Xenopus laevis embryos. Cell Cycle 5, 1687-98.

Chesnel, F., Bazile, F., Pascal, A. and Kubiak, J. Z. (2007). Cyclin B2/cyclin-dependent kinase1 dissociation precedes CDK1 Thr-161 dephosphorylation upon M-phase promoting factor inactivation in Xenopus laevis cell-free extract. Int J Dev Biol 51, 297-305.

Chung, E. and Chen, R. H. (2003). Phosphorylation of Cdc20 is required for its inhibition by the spindle checkpoint. Nat Cell Biol 5, 748-53.

Creutz, C. E., Tomsig, J. L., Snyder, S. L., Gautier, M. C., Skouri, F., Beisson, J. and Cohen, J. (1998). The copines, a novel class of $\mathrm{C} 2$ domain-containing, calcium-dependent, phospholipid-binding proteins conserved from Paramecium to humans. J Biol Chem 273, 1393-402.

Damer, C. K., Bayeva, M., Kim, P. S., Ho, L. K., Eberhardt, E. S., Socec, C. I., Lee, J. S., Bruce, E. A., Goldman-Yassen, A. E. and Naliboff, L. C. (2007). Copine A is required for cytokinesis, contractile vacuole function, and development in Dictyostelium. Eukaryot Cell 6, 430-42.

De Clercq, A. and Inze, D. (2006). Cyclin-dependent kinase inhibitors in yeast, animals, and plants: a functional comparison. Crit Rev Biochem Mol Biol 41, 293-313.

Dix, D. J., Allen, J. W., Collins, B. W., Mori, C., Nakamura, N., Poorman-Allen, P., Goulding, E. H. and Eddy, E. M. (1996). Targeted gene disruption of Hsp70-2 results in failed meiosis, germ cell apoptosis, and male infertility. Proc Natl Acad Sci U S A 93, 3264-8.

Elsasser, S., Lou, F., Wang, B., Campbell, J. L. and Jong, A. (1996). Interaction between yeast Cdc6 protein and B-type cyclin/Cdc28 kinases. Mol Biol Cell 7, 1723-35.

Fisher DL, Mandart E, Dorée M. (2000). Hsp90 is required for c-Mos activation and biphasic MAP kinase activation in Xenopus oocytes. EMBO J. 19, 1516-24.

Gautier, J., Norbury, C., Lohka, M., Nurse, P. and Maller, J. (1988). Purified maturation-promoting factor contains the product of a Xenopus homolog of the fission yeast cell cycle control gene cdc2+. Cell 54, 433-9.

Geraci, F., Agueli, C., Giudice, G. and Sconzo, G. (2003). Localization of HSP70, Cdc2, and cyclin B in sea urchin oocytes in non-stressed conditions. Biochem Biophys Res Commun 310, 748-53.

Gong, D. and Ferrell, J. E., Jr. (2010). The roles of cyclin A2, b1, and b2 in early and late mitotic events. Mol Biol Cell 21, 3149-61.

Hochegger, H., Klotzbucher, A., Kirk, J., Howell, M., le Guellec, K., Fletcher, K., Duncan, T., Sohail, M. and Hunt, T. (2001). New B-type cyclin synthesis is required between meiosis I and II during Xenopus oocyte maturation. Development 128, 3795-807.

Hofmann, B., Hecht, H. J. and Flohe, L. (2002). Peroxiredoxins. Biol Chem 383, 347-64. 
Huo, L. J., Yu, L. Z., Liang, C. G., Fan, H. Y., Chen, D. Y. and Sun, Q. Y. (2005). Cell-cycledependent subcellular localization of cyclin B1, phosphorylated cyclin B1 and p34cdc2 during oocyte meiotic maturation and fertilization in mouse. Zygote 13, 45-53.

Hutchins JR, Toyoda Y, Hegemann B, Poser I, Hériché JK, Sykora MM, Augsburg M, Hudecz O, Buschhorn BA, Bulkescher J, Conrad C, Comartin D, Schleiffer A, Sarov M, Pozniakovsky A, Slabicki MM, Schloissnig S, Steinmacher I, Leuschner M, Ssykor A, Lawo S, Pelletier L, Stark H, Nasmyth K, Ellenberg J, Durbin R, Buchholz F, Mechtler K, Hyman AA, Peters JM. (2010). Systematic analysis of human protein complexes identifies chromosome segregation proteins. Science 328, 593-9.

Keller, A., Nesvizhskii, A. I., Kolker, E. and Aebersold, R. (2002). Empirical statistical model to estimate the accuracy of peptide identifications made by MS/MS and database search. Anal Chem 74, 5383-92.

Kõivomägi M, Valk E, Venta R, Iofik A, Lepiku M, Morgan DO, Loog M. (2011). Dynamics of Cdk1 substrate specificity during the cell cycle. Mol Cell. 42, 610-23.

Krasinska L, Besnard E, Cot E, Dohet C, Méchali M, Lemaitre JM, Fisher D. (2008). Cdk1 and Cdk2 activity levels determine the efficiency of replication origin firing in Xenopus. EMBO J. 27, 75869.

Kubiak JZ, Weber M, de Pennart H, Winston NJ, Maro B. (1993). The metaphase II arrest in mouse oocytes is controlled through microtubule-dependent destruction of cyclin $\mathrm{B}$ in the presence of CSF. EMBO J. 12, 3773-8.

Kubiak J.Z. \& El Dika M. (2011). Canonical and alternative pathways in Cyclin-Dependent Kinase 1/cyclin B inactivation upon M-phase exit in Xenopus laevis cell-free extracts. Enzyme Res. (in press).

Kumar, J., Yu, H. and Sheetz, M. P. (1995). Kinectin, an essential anchor for kinesin-driven vesicle motility. Science 267, 1834-7.

Labbe, J. C., Capony, J. P., Caput, D., Cavadore, J. C., Derancourt, J., Kaghad, M., Lelias, J. M., Picard, A. and Doree, M. (1989). MPF from starfish oocytes at first meiotic metaphase is a heterodimer containing one molecule of cdc2 and one molecule of cyclin B. EMBO J 8, 3053-8.

Laemmli, U. K. (1970). Cleavage of structural proteins during the assembly of the head of bacteriophage T4. Nature 227, 680-5.

Lohka, M. J., Hayes, M. K. and Maller, J. L. (1988). Purification of maturation-promoting factor, an intracellular regulator of early mitotic events. Proc Natl Acad Sci U S A 85, 3009-13.

Lorca, T., Bernis, C., Vigneron, S., Burgess, A., Brioudes, E., Labbe, J. C. and Castro, A. (2010). Constant regulation of both the MPF amplification loop and the Greatwall-PP2A pathway is required for metaphase II arrest and correct entry into the first embryonic cell cycle. J Cell Sci 123, 2281-91.

Masui, Y. and Markert, C. L. (1971). Cytoplasmic control of nuclear behavior during meiotic maturation of frog oocytes. J Exp Zool 177, 129-45.

McConnell, B. B., Gregory, F. J., Stott, F. J., Hara, E. and Peters, G. (1999). Induced expression of p16(INK4a) inhibits both CDK4- and CDK2-associated kinase activity by reassortment of cyclinCDK-inhibitor complexes. Mol Cell Biol 19, 1981-9.

Miniowitz-Shemtov S, Teichner A, Sitry-Shevah D, Hershko A. (2010). ATP is required for the release of the anaphase-promoting complex/cyclosome from inhibition by the mitotic checkpoint. Proc Natl Acad Sci U S A. 107, 5351-6.

Mochida, S. and Hunt, T. (2007). Calcineurin is required to release Xenopus egg extracts from meiotic M phase. Nature 449, 336-40.

Morgan, D. O. (1995). Principles of CDK regulation. Nature 374, 131-4.

Mueller, P. R., Coleman, T. R., Kumagai, A. and Dunphy, W. G. (1995). Myt1: a membraneassociated inhibitory kinase that phosphorylates $\mathrm{Cdc} 2$ on both threonine-14 and tyrosine- 15 . Science 270, 86-90.

Nagaoka, R., Abe, H., Kusano, K. and Obinata, T. (1995). Concentration of cofilin, a small actinbinding protein, at the cleavage furrow during cytokinesis. Cell Motil Cytoskeleton 30, 1-7.

Nakamura, N., Tokumoto, T., Ueno, S. and Iwao, Y. (2005). The cytoskeleton-dependent localization of cdc2/cyclin B in blastomere cortex during Xenopus embryonic cell cycle. Mol Reprod Dev 72, $336-45$. 
Nesvizhskii, A. I., Keller, A., Kolker, E. and Aebersold, R. (2003). A statistical model for identifying proteins by tandem mass spectrometry. Anal Chem 75, 4646-58.

Nguyen, T. Q., Sawa, H., Okano, H. and White, J. G. (2000). The C. elegans septin genes, unc-59 and unc-61, are required for normal postembryonic cytokineses and morphogenesis but have no essential function in embryogenesis. $J$ Cell Sci 113 Pt 21, 3825-37.

Nishiyama, A., Tachibana, K., Igarashi, Y., Yasuda, H., Tanahashi, N., Tanaka, K., Ohsumi, K. and Kishimoto, T. (2000). A nonproteolytic function of the proteasome is required for the dissociation of Cdc2 and cyclin B at the end of M phase. Genes Dev 14, 2344-57.

Nishiyama, T., Yoshizaki, N., Kishimoto, T. and Ohsumi, K. (2007). Transient activation of calcineurin is essential to initiate embryonic development in Xenopus laevis. Nature 449, 341-5.

Parry, D., Mahony, D., Wills, K. and Lees, E. (1999). Cyclin D-CDK subunit arrangement is dependent on the availability of competing INK4 and p21 class inhibitors. Mol Cell Biol 19, 177583.

Patra, D. and Dunphy, W. G. (1996). Xe-p9, a Xenopus Suc1/Cks homolog, has multiple essential roles in cell cycle control. Genes Dev 10, 1503-15.

Riabowol, K., Draetta, G., Brizuela, L., Vandre, D. and Beach, D. (1989). The cdc2 kinase is a nuclear protein that is essential for mitosis in mammalian cells. Cell 57, 393-401.

Rusnak, F. and Mertz, P. (2000). Calcineurin: form and function. Physiol Rev 80, 1483-521.

Santella, L., Ercolano, E., Lim, D., Nusco, G. A. and Moccia, F. (2003). Activated M-phasepromoting factor (MPF) is exported from the nucleus of starfish oocytes to increase the sensitivity of the Ins(1,4,5)P3 receptors. Biochem Soc Trans 31, 79-82.

Savitsky, P. A. and Finkel, T. (2002). Redox regulation of Cdc25C. J Biol Chem 277, 20535-40.

Spiliotis, E. T., Kinoshita, M. and Nelson, W. J. (2005). A mitotic septin scaffold required for Mammalian chromosome congression and segregation. Science 307, 1781-5.

Takeo, S., Hawley, R. S. and Aigaki, T. (2010). Calcineurin and its regulation by Sra/RCAN is required for completion of meiosis in Drosophila. Dev Biol 344, 957-67.

Thibier C, De Smedt V, Poulhe R, Huchon D, Jessus C, Ozon R. (1997). In vivo regulation of cytostatic activity in Xenopus metaphase II-arrested oocytes. Dev Biol. 185, 55-66.

Trinkle-Mulcahy L, Boulon S, Lam YW, Urcia R, Boisvert FM, Vandermoere F, Morrice NA, Swift S, Rothbauer U, Leonhardt H, Lamond A. (2008). Identifying specific protein interaction partners using quantitative mass spectrometry and bead proteomes. J Cell Biol. 183, 223-39.

van Zon, W., Ogink, J., ter Riet, B., Medema, R. H., te Riele, H. and Wolthuis, R. M. (2010). The $\mathrm{APC} / \mathrm{C}$ recruits cyclin $\mathrm{B} 1-\mathrm{Cdk} 1-\mathrm{Cks}$ in prometaphase before $\mathrm{D}$ box recognition to control mitotic exit. J Cell Biol 190, 587-602.

Vogel L, Baratte B, Détivaud L, Azzi L, Leopold P, Meijer L. (2002). Molecular cloning and characterisation of p15(CDK-BP), a novel CDK-binding protein. Biochim Biophys Acta. 1589, 219-31.

Wang, R., He, G., Nelman-Gonzalez, M., Ashorn, C. L., Gallick, G. E., Stukenberg, P. T., Kirschner, M. W. and Kuang, J. (2007). Regulation of Cdc25C by ERK-MAP kinases during the G2/M transition. Cell 128, 1119-32.

Yalcin A, Clem BF, Simmons A, Lane A, Nelson K, Clem AL, Brock E, Siow D, Wattenberg B, Telang S, Chesney J. (2009). Nuclear targeting of 6-phosphofructo-2-kinase (PFKFB3) increases proliferation via cyclin-dependent kinases. J Biol Chem. 284, 24223-32.

Yim H. \& Erikson R.L. (2010). Cell division cycle 6, a mitotic substrate of polo-like kinase 1, regulates chromosomal segregation mediated by cyclin-dependent kinase 1 and separase. Proc Natl Acad Sci U S A. 107, 19742-7.

Yudkovsky, Y., Shteinberg, M., Listovsky, T., Brandeis, M. and Hershko, A. (2000). Phosphorylation of Cdc20/fizzy negatively regulates the mammalian cyclosome/APC in the mitotic checkpoint. Biochem Biophys Res Commun 271, 299-304.

Zhu, D., Dix, D. J. and Eddy, E. M. (1997). HSP70-2 is required for CDC2 kinase activity in meiosis I of mouse spermatocytes. Development 124, 3007-14.

\section{Figure legends}


Fig. 1. Co-immunoprecipitation of CDK1 and its partners during M-phase and M-phase exit. (A) Egg activation was checked by following Mcm4 phosphorylation status and Cyclin B2 (CycB2) abundance by immunoblotting of extracts of eggs taken 0, 3, 7, 9, 15, 30 min after calcium ionophore addition. (B) Co-immunoprecipitation of CDK1 and its partner (CycB2) during M-phase (T0) and M-phase exit (T7) was checked by following its presence either in protein fractions bound to beads (Bound) or in the non-retained fractions (Unbound). The presence of $\mathrm{CDK} 1$ and $\mathrm{CycB} 2$ was also checked in negative controls (C-, naked beads) in order to control the specificity of the interactions. (C) Comparative protein profiles of bound fraction of each samples: M-phase CDK1 IP (T0), its negative control (c- T0), M-phase exit CDK1 IP (T7) and its negative control (c- T7). Eluted proteins were resolved on SDS-PAGE and revealed with SYPRO Ruby staining.

Fig. 2. Distribution of protein functions based on Gene Ontology (GO) classification and bibliography of putative MPF interactors during M-phase (IP T0) and M-phase exit (IP T7) identified by CDK1 immunoprecipitation followed by MS analysis.

Fig. 3. Co-precipitation of CDK1 and its partners using p9 beads during M-phase and Mphase exit. (A) Egg activation was checked by following Mcm4 phosphorylation status and CycB2 abundance by immunoblotting extracts of eggs taken 0, 3, 7, 9, 15, 30 min after calcium ionophore addition. (B) Co-precipitation of CDK1 and its partner (CycB2) during Mphase (T0) and M-phase exit (T7) was checked by following its presence either in protein fractions bound to the beads (Bound) or in the non-retained fractions (Unbound). The presence of CDK1 and $\mathrm{CycB} 2$ was also checked in negative controls (C-, naked beads) in order to control the specificity of the interactions. (C) Comparative protein profiles of bound fraction of each samples: M-phase CDK1 p9 precipitation (T0), its negative control (c- T0), M-phase exit CDK1 p9 precipitation (T7) and its negative control (c- T7). Eluted proteins were resolved on SDS-PAGE and revealed with SYPRO Ruby staining.

Fig. 4. Distribution of protein functions based on Gene Ontology (GO) classification and bibliography of putative CDK1 interactors during M-phase (P9 T0) and M-phase exit (P9 T7) identified by CDK1 precipitation via $\mathrm{p} 9$ beads followed by MS analysis. 
Fig. 5. Common putative CDK1 interactors between IP and $\mathrm{p} 9$ precipitation during M-phase and M-phase exit. (A) Six proteins are common between IP and p9 precipitation M-phase samples (Cdc2A, Cdc2B, CycB2, CycB4, HspA8 and peroxiredoxine-2). (B) Eight proteins are common between IP and p9 precipitation M-phase exit samples (Cdc2A, Cdc2B, CycB2, CycB4, HspA8, Peroxiredoxine-2, Pyruvate kinase and the alfa subunit of ATPase). (C) Six proteins are common between IP and p9 precipitation M-phase and M-phase exit samples (Cdc2A, Cdc2B, CycB2, CycB4, HspA8 and Peroxiredoxine-2). 
Table 1. Potential interactors of CDK1 identified by mass spectrometry from CDK1 immunoprecipitation in metaphase II arrest $X$. laevis UFE

\begin{tabular}{|c|c|c|c|c|c|c|}
\hline & Protein name & $\begin{array}{l}\text { Accession } \\
\text { Number }\end{array}$ & $\begin{array}{c}\text { Molecular } \\
\text { Weight } \\
\text { (kDa) }\end{array}$ & $\begin{array}{c}\text { Unique } \\
\text { peptide c- } \\
\text { T0 }\end{array}$ & $\begin{array}{c}\text { Unique } \\
\text { peptide } \\
\text { IP T0 }\end{array}$ & Biological process \\
\hline 1 & kinectin 1 & Q08B03 & 97 & 0 & 12 & $\begin{array}{l}\text { Microtubule-based } \\
\text { movement }\end{array}$ \\
\hline 2 & Cell division control protein 2-A & P35567 & 35 & 0 & 11 & Cell division \\
\hline 3 & Heat Shock Protein A8 & Q7ZTK6 & 71 & 1 & 9 & ATP binding \\
\hline 4 & Cyclin B2 & Q6PA39 & 44 & 0 & 5 & Cell division \\
\hline 5 & Mitogen-activated protein kinase 1 & P26696 & 41 & 0 & 4 & Cell cycle \\
\hline 6 & Cyclin B4 & Q98TI3 & 44 & 0 & 4 & Cell division \\
\hline 7 & Egg cortical granule lectin & Q91719 & 34 & 0 & 4 & Signal transduction \\
\hline 8 & $\begin{array}{l}\text { Transitional endoplasmic reticulum } \\
\text { ATPase }\end{array}$ & P23787 & 89 & 0 & 3 & Transport \\
\hline 9 & Histone deacetylase 10 & Q569T0 & 77 & 0 & 3 & hydrolase activity \\
\hline 10 & Cell division control protein 2-B & P24033 & 35 & 0 & 3 & Cell division \\
\hline 11 & T-complex protein 1 gamma subunit & P50143 & 61 & 0 & 3 & Protein folding \\
\hline 12 & Sorcin & A2VDA2 & 22 & 0 & 2 & Calcium ion binding \\
\hline 13 & RuvB like protein & Q0IH85 & 51 & 0 & 2 & ATP binding \\
\hline 14 & Heat shock protein $\mathrm{d} 1$ & Q6IP60 & 62 & 0 & 2 & Protein refolding \\
\hline 15 & T-complex protein 1 subunit 5 & AOAUT4 & 59 & 0 & 2 & Protein folding \\
\hline 16 & XIZPA protein & A1L3D9 & 78 & 0 & 2 & Single fertilization \\
\hline 17 & Peroxiredoxin-2 & Q6ING3 & 22 & 0 & 1 & $\begin{array}{l}\text { cell redox } \\
\text { homeostasis }\end{array}$ \\
\hline 18 & Nucleoporin & Q6PAY1 & 55 & 0 & 1 & $\begin{array}{l}\text { transmembrane } \\
\text { transport }\end{array}$ \\
\hline 19 & $\begin{array}{l}\text { Chaperonin containing TCP1, subunit } \\
7\end{array}$ & Q5XGK8 & 52 & 0 & 1 & Protein folding \\
\hline 20 & Calcineurin A & O57438 & 58 & 0 & 1 & Cell division \\
\hline 21 & Copin & Q6P7H2 & 59 & 0 & 1 & $\begin{array}{l}\text { vesicle-mediated } \\
\text { transpor }\end{array}$ \\
\hline 22 & Egg envelope glycoprotein & Q4VGP0 & 108 & 0 & 1 & Unknown \\
\hline 23 & Nupl1 protein & A4FU91 & 60 & 0 & 1 & $\begin{array}{l}\text { transmembrane } \\
\text { transport }\end{array}$ \\
\hline 24 & Hadh2-prov protein & Q6DCM8 & 27 & 0 & 1 & oxidation reduction \\
\hline 25 & Acad9-prov protein & Q6DDF2 & 68 & 0 & 1 & oxidation reduction \\
\hline 26 & $\begin{array}{l}\text { Aldehyde dehydrogenase family } 18 \\
\text { member } \mathrm{A} 1\end{array}$ & Q6GMF0 & 89 & 0 & 1 & $\begin{array}{l}\text { proline biosynthetic } \\
\text { process }\end{array}$ \\
\hline 27 & Egg envelope component ZPAX & B4F6R0 & 102 & 0 & 1 & Unknown \\
\hline 28 & LOC100049148 protein & A4QN33 & 95 & 0 & 1 & Unknown \\
\hline 29 & $\begin{array}{l}\text { Thyroid hormone receptor-associated } \\
\text { protein } 3 \text { (TRAP150) }\end{array}$ & Q5BJ39 & 108 & 0 & 1 & $\begin{array}{l}\text { regulation of } \\
\text { transcription }\end{array}$ \\
\hline 30 & MGC68559 protein & Q6PAA1 & 24 & 0 & 1 & Calcium ion binding \\
\hline
\end{tabular}


Table 2: Potential interactors of CDK1 identified by mass spectrometry from CDK1 immunoprecipitation in activated $X$. laevis UFE (proteins highlighted in grey are common between metaphase II arrested and activated UFE)

\begin{tabular}{|c|c|c|c|c|c|c|}
\hline & Protein name & $\begin{array}{l}\text { Accession } \\
\text { Number }\end{array}$ & $\begin{array}{c}\text { Molecular } \\
\text { Weight } \\
\text { (kDa) }\end{array}$ & $\begin{array}{c}\text { Unique } \\
\text { peptide } \\
\text { c- T7 }\end{array}$ & $\begin{array}{c}\text { Unique } \\
\text { peptide } \\
\text { IP T7 }\end{array}$ & $\begin{array}{l}\text { Biological process } \\
\text { (GO annotation) }\end{array}$ \\
\hline 1 & Kinectin 1 & Q08B03 & 97 & 0 & 9 & $\begin{array}{l}\text { Microtubule-based } \\
\text { movement }\end{array}$ \\
\hline 2 & Cell division control protein 2-A & P35567 & 35 & 2 & 8 & Cell division \\
\hline 3 & Mitogen-activated protein kinase 1 & P26696 & 41 & 0 & 4 & Cell cycle \\
\hline 4 & T-complex protein 1 gamma subunit & P50143 & 61 & 0 & 4 & Protein folding \\
\hline 5 & Heat Shock Protein A8 & Q7ZTK6 & 71 & 1 & 4 & ATP binding \\
\hline 6 & $\begin{array}{l}\text { Transitional endoplasmic reticulum } \\
\text { ATPase }\end{array}$ & P23787 & 89 & 0 & 3 & Transport \\
\hline 7 & Histone deacetylase 10 & Q569T0 & 77 & 0 & 3 & hydrolase activity \\
\hline 8 & Nucleoporin & Q6PAY1 & 55 & 0 & 3 & $\begin{array}{l}\text { transmembrane } \\
\text { transport }\end{array}$ \\
\hline 9 & Calcineurin A & 057438 & 58 & 0 & 3 & Cell division \\
\hline 10 & Copin & Q6P7H2 & 59 & 0 & 3 & $\begin{array}{l}\text { vesicle-mediated } \\
\text { transport }\end{array}$ \\
\hline 11 & $\begin{array}{l}\text { Member of T-complex protein } 1 \\
\text { chaperonin family }\end{array}$ & Q6GMA6 & 58 & 0 & 3 & Protein folding \\
\hline 12 & ATP synthase beta subunit & Q7ZWR6 & 56 & 0 & 3 & $\begin{array}{l}\text { ATP biosynthetic } \\
\text { process }\end{array}$ \\
\hline 13 & Hadh2-prov protein & Q6DCM8 & 27 & 0 & 3 & oxidation reduction \\
\hline 14 & Arginyl aminopeptidase & Q641C7 & 70 & 0 & 3 & Proteolysis \\
\hline 15 & Cyclin B2 & Q6PA39 & 44 & 0 & 2 & Cell division \\
\hline 16 & Cell division control protein 2-B & P24033 & 35 & 0 & 2 & Cell division \\
\hline 17 & Chaperonin containing TCP1, subunit 7 & Q5XGK8 & 52 & 0 & 2 & Protein folding \\
\hline 18 & RuvB like protein & Q0IH85 & 51 & 0 & 2 & ATP binding \\
\hline 19 & Nupl1 protein & A4FU91 & 60 & 0 & 2 & $\begin{array}{l}\text { transmembrane } \\
\text { transport }\end{array}$ \\
\hline 20 & $\begin{array}{l}\text { Dynein, cytoplasmic 1, intermediate } \\
\text { chain } 2\end{array}$ & Q5U238 & 72 & 0 & 2 & Transport \\
\hline 21 & $\begin{array}{l}\text { Aldehyde dehydrogenase family } 18 \\
\text { member } A 1\end{array}$ & Q6GMF0 & 89 & 0 & 2 & $\begin{array}{l}\text { proline biosynthetic } \\
\text { process }\end{array}$ \\
\hline 22 & $\begin{array}{l}\text { ATPase family AAA domain-containing } \\
\text { protein 3-A }\end{array}$ & Q58E76 & 67 & 0 & 2 & ATP binding \\
\hline 23 & ATP synthase subunit alpha & Q68EY5 & 60 & 0 & 2 & $\begin{array}{l}\text { ATP biosynthetic } \\
\text { process }\end{array}$ \\
\hline 24 & $\begin{array}{l}\text { Von Willebrand factor A domain } \\
\text { containing } 5 \mathrm{~A} \text {, gene } 2\end{array}$ & Q6IND5 & 94 & 0 & 2 & Unknown \\
\hline 25 & LOC733268 protein & Q0IH65 & 27 & 0 & 2 & Unknown \\
\hline 26 & Acyltransferase & Q642P5 & 54 & 0 & 2 & $\begin{array}{l}\text { fatty-acyl-CoA } \\
\text { biosynthetic process }\end{array}$ \\
\hline 27 & LOC431925 protein & Q6NR96 & 210 & 0 & 1 & Proteolysis \\
\hline 28 & Cyclin B4 & Q98TI3 & 44 & 0 & 1 & Cell division \\
\hline 29 & Peroxiredoxin-2 & Q6ING3 & 22 & 0 & 1 & cell redox homeostasis \\
\hline 30 & Sorcin & A2VDA2 & 22 & 0 & 1 & Calcium ion binding \\
\hline 31 & Heat shock protein d1 & Q6IP60 & 62 & 0 & 1 & Protein refolding \\
\hline 32 & T-complex protein 1 subunit 5 & AOAUT4 & 59 & 0 & 1 & Protein folding \\
\hline 33 & Acad9-prov protein & Q6DDF2 & 68 & 0 & 1 & oxidation reduction \\
\hline 34 & Nuclear pore glycoprotein & A2BDA4 & 50 & 0 & 1 & transport \\
\hline 35 & Ruvbl1 protein & Q6GR29 & 50 & 0 & 1 & ATP binding \\
\hline
\end{tabular}




\begin{tabular}{llccccc}
\hline Protein name & $\begin{array}{c}\text { Accession } \\
\text { Number }\end{array}$ & $\begin{array}{c}\text { Molecular } \\
\text { Weight } \\
\text { (kDa) }\end{array}$ & $\begin{array}{c}\text { Unique } \\
\text { peptide } \\
\text { c- T7 }\end{array}$ & $\begin{array}{c}\text { Unique } \\
\text { peptide } \\
\text { IP T7 }\end{array}$ & $\begin{array}{c}\text { Biological process } \\
\text { (GO annotation) }\end{array}$ \\
\hline \hline 36 & Ratireb-prov protein & Q7ZY37 & 99 & 0 & 1 & Metabolic process \\
37 & Apx protein & B7ZSK3 & 159 & 0 & 1 & Cell shape \\
38 & Dlst-prov protein & Q7ZXF6 & 49 & 0 & 1 & tricarboxylic acid cycle \\
39 & Grp58-prov protein & Q7ZWU3 & 56 & 0 & 1 & cell redox homeostasis \\
40 & Pyruvate kinase & Q7ZY25 & 57 & 0 & 1 & Glycolysis \\
41 & Septin 9 & Q498G4 & 39 & 0 & 1 & Cell cycle \\
42 & Nmp200-prov protein & Q7ZXW4 & 55 & 0 & 1 & Protein ubiquitination
\end{tabular}


Table 3: Proteins identified by mass spectrometry from $\mathrm{p} 9$ precipitation in Metaphase II arrested $X$. laevis UFE (proteins highlighted in grey are common between metaphase II arrested and activated UFE)

\begin{tabular}{|c|c|c|c|c|c|c|}
\hline & Protein name & $\begin{array}{l}\text { Accession } \\
\text { Number }\end{array}$ & $\begin{array}{l}\text { Molecular } \\
\text { Weight } \\
\text { (kDa) }\end{array}$ & $\begin{array}{l}\text { Unique } \\
\text { peptide } \\
\text { c- P9 T0 }\end{array}$ & $\begin{array}{l}\text { Unique } \\
\text { peptide } \\
\text { P9 T0 }\end{array}$ & $\begin{array}{l}\text { Biological } \\
\text { process }\end{array}$ \\
\hline \multirow{6}{*}{$\begin{array}{l}1 \\
2 \\
3 \\
4 \\
5 \\
6\end{array}$} & \multirow{2}{*}{$\begin{array}{l}\text { Cell division control protein 2- } \\
\text { A } \\
\text { Heat shock protein A8 }\end{array}$} & P35567 & 35 & 0 & 9 & Cell division \\
\hline & & Q7ZTK6 & 71 & 0 & 6 & ATP bindind \\
\hline & \multirow{4}{*}{$\begin{array}{l}\text { Cyclin B4 } \\
\text { Cyclin B2 } \\
\text { Cyclin B5 } \\
\text { Protein-L-isoaspartate O- } \\
\text { methyltransferase }\end{array}$} & Q98TI3 & 44 & 0 & 5 & Cell division \\
\hline & & P13351 & 44 & 0 & 4 & Cell division \\
\hline & & Q5HZQ4 & 44 & 0 & 3 & Cell division \\
\hline & & Q7SZS4 & 25 & 0 & 2 & $\begin{array}{l}\text { Protein } \\
\text { modification } \\
\text { process }\end{array}$ \\
\hline \multirow{2}{*}{$\begin{array}{l}7 \\
8\end{array}$} & \multirow{2}{*}{$\begin{array}{l}\text { Cell division control protein 2- } \\
\text { B } \\
\text { TRAF2 and NCK-interacting } \\
\text { protein kinase }\end{array}$} & P24033 & 35 & 0 & 2 & Cell division \\
\hline & & Q32NV8 & 57 & 0 & 2 & $\begin{array}{l}\text { Protein amino acid } \\
\text { phosphorylation } \\
\text { process }\end{array}$ \\
\hline \multirow{2}{*}{$\begin{array}{r}9 \\
10\end{array}$} & \multirow{2}{*}{$\begin{array}{l}\text { Cyclin B1 } \\
\text { Peroxiredoxin-2 }\end{array}$} & P13350 & 45 & 0 & 2 & Cell division \\
\hline & & Q6ING3 & 22 & 1 & 2 & $\begin{array}{c}\text { cell redox } \\
\text { homeostasis }\end{array}$ \\
\hline \multirow{2}{*}{$\begin{array}{l}11 \\
12\end{array}$} & \multirow{2}{*}{$\begin{array}{l}\text { Galectin-VIla } \\
\text { XIGST Superfamily1-1 protein }\end{array}$} & Q7ZSY1 & 28 & 0 & 1 & sugar binding \\
\hline & & Q7SZA7 & 23 & 0 & 1 & $\begin{array}{l}\text { Prostaglandin-D } \\
\text { synthase activity }\end{array}$ \\
\hline 13 & NIF3-like protein 1 & QOIHC9 & 37 & 0 & 1 & $\begin{array}{l}\text { Regulation of } \\
\text { transcription }\end{array}$ \\
\hline \multirow{2}{*}{$\begin{array}{l}14 \\
15\end{array}$} & \multirow{2}{*}{$\begin{array}{l}\text { Ribosomal protein S30 } \\
\text { Cofilin-1-A }\end{array}$} & Q4KLF0 & 15 & 0 & 1 & Translation \\
\hline & & P45695 & 19 & 0 & 1 & $\begin{array}{c}\text { Actin filament } \\
\text { depolymerisation/ } \\
\text { cytokinesis }\end{array}$ \\
\hline \multirow{2}{*}{$\begin{array}{l}16 \\
17\end{array}$} & \multirow{2}{*}{$\begin{array}{l}\text { CDK2 } \\
\text { Double-stranded RNA-binding } \\
\text { protein A }\end{array}$} & Q6IRQ7 & 34 & 0 & 1 & Cell cycle \\
\hline & & Q91836 & 33 & 0 & 1 & $\begin{array}{l}\text { RNA-mediated } \\
\text { gene silencing }\end{array}$ \\
\hline 18 & Heat shock protein a5 & Q8AVE3 & 72 & 0 & 1 & ATP bindind \\
\hline 19 & Junction plakoglobin & P30998 & 82 & 0 & 1 & Cell adhesion \\
\hline
\end{tabular}


Table 4: Proteins identified by mass spectrometry from $\mathrm{p} 9$ precipitation in activated $X$. laevis UFE (proteins highlighted in grey are common between metaphase II arrested and activated UFE)

\begin{tabular}{|c|c|c|c|c|c|c|}
\hline & Protein name & $\begin{array}{l}\text { Accession } \\
\text { Number }\end{array}$ & $\begin{array}{l}\text { Molecular } \\
\text { Weight } \\
\text { (kDa) }\end{array}$ & $\begin{array}{c}\text { Unique } \\
\text { peptide } \\
\text { C- P9 } \\
\text { T8 }\end{array}$ & $\begin{array}{l}\text { Unique } \\
\text { peptide } \\
\text { P9 T8 }\end{array}$ & $\begin{array}{l}\text { Biological } \\
\text { process/molecular } \\
\text { function }\end{array}$ \\
\hline 1 & Heat shock protein A8 & Q7ZTK6 & 71 & 1 & 9 & ATP bindind \\
\hline 2 & $\begin{array}{l}\text { Cell division control protein } \\
2-A\end{array}$ & P35567 & 35 & 0 & 7 & Cell division \\
\hline 3 & Heat shock protein 9 & Q7ZX34 & 73 & 0 & 4 & ATP bindind \\
\hline 4 & $\begin{array}{l}\text { Protein-L-isoaspartate O- } \\
\text { methyltransferase }\end{array}$ & Q7SZS4 & 25 & 0 & 3 & $\begin{array}{c}\text { Protein modification } \\
\text { process }\end{array}$ \\
\hline 5 & XIGSTS1-1 & Q7SZA7 & 23 & 0 & 3 & $\begin{array}{l}\text { Prostaglandin-D } \\
\text { synthase activity }\end{array}$ \\
\hline 6 & $\begin{array}{l}\text { Ferrochelatase, } \\
\text { mitochondrial }\end{array}$ & O57478 & 46 & 0 & 3 & $\begin{array}{l}\text { heme biosynthetic } \\
\text { process }\end{array}$ \\
\hline 7 & Cyclin B2 & P13351 & 44 & 0 & 2 & Cell division \\
\hline 8 & Cyclin B4 & Q98TI3 & 44 & 0 & 2 & Cell division \\
\hline 9 & Peroxiredoxin-2 & Q6ING3 & 22 & 0 & 2 & $\begin{array}{c}\text { cell redox } \\
\text { homeostasis }\end{array}$ \\
\hline 10 & $\begin{array}{l}\text { Peptidyl-prolyl cis-trans } \\
\text { isomerase }\end{array}$ & Q5XGR3 & 24 & 0 & 2 & protein folding \\
\hline 11 & NIF3-like protein 1 & Q0IHC9 & 37 & 0 & 2 & $\begin{array}{l}\text { Regulation of } \\
\text { transcription }\end{array}$ \\
\hline 12 & Ribosomal protein S30 & Q4KLF0 & 15 & 0 & 2 & Translation \\
\hline 13 & $\begin{array}{l}\text { electron-transfer- } \\
\text { flavoprotein, beta } \\
\text { polypeptide }\end{array}$ & Q6PBB7 & 28 & 0 & 2 & $\begin{array}{l}\text { electron carrier } \\
\text { activity }\end{array}$ \\
\hline 14 & $\begin{array}{l}\text { RNA terminal phosphate } \\
\text { cyclase domain } 1\end{array}$ & Q6GMZ1 & 38 & 0 & 2 & RNA processing \\
\hline 15 & Galectin-VIla & Q7ZSY1 & 28 & 0 & 1 & sugar binding \\
\hline 16 & Cofilin-1-A & P45695 & 19 & 0 & 1 & $\begin{array}{c}\text { Actin filament } \\
\text { depolymerisation/ } \\
\text { cytokinesis }\end{array}$ \\
\hline 17 & Rpl3-prov protein & Q7ZYR1 & 46 & 0 & 1 & Translation \\
\hline 18 & CDK2 & Q6IRQ7 & 34 & 0 & 1 & Cell division \\
\hline 19 & $\begin{array}{l}\text { Cell division control protein } \\
2-B\end{array}$ & P24033 & 35 & 0 & 1 & Cell division \\
\hline 20 & $\begin{array}{l}\text { TRAF2 and NCK- } \\
\text { interacting protein kinase }\end{array}$ & Q32NV8 & 57 & 0 & 1 & $\begin{array}{l}\text { Protein amino acid } \\
\text { phosphorylation } \\
\text { process }\end{array}$ \\
\hline 21 & Exportin-2 & Q6GMY9 & 110 & 0 & 1 & Protein transport \\
\hline 22 & $\begin{array}{l}\text { Double-stranded RNA- } \\
\text { binding protein A }\end{array}$ & Q91836 & 33 & 0 & 1 & $\begin{array}{l}\text { RNA-mediated } \\
\text { gene silencing }\end{array}$ \\
\hline 23 & Hspa5 protein & Q8AVE3 & 72 & 0 & 1 & ATP bindind \\
\hline 24 & $\begin{array}{l}\text { Uncharacterized protein } \\
\text { KIAA0090 }\end{array}$ & Q6NRB9 & 111 & 0 & 1 & Unknown \\
\hline 25 & Pyruvate kinase & Q6PA20 & 58 & 0 & 1 & Glycolysis \\
\hline 26 & Glucagon & B7ZQU9 & 25 & 0 & 1 & Hormone activity \\
\hline 27 & $\begin{array}{l}\text { Small nuclear } \\
\text { ribonucleoprotein Sm D3 }\end{array}$ & P62323 & 14 & 0 & 1 & mRNA processing \\
\hline
\end{tabular}




\begin{tabular}{|c|c|c|c|c|c|c|}
\hline & Protein name & $\begin{array}{l}\text { Accession } \\
\text { Number }\end{array}$ & $\begin{array}{l}\text { Molecular } \\
\text { Weight } \\
\text { (kDa) }\end{array}$ & $\begin{array}{c}\text { Unique } \\
\text { peptide } \\
\text { C- P9 } \\
\text { T8 }\end{array}$ & $\begin{array}{l}\text { Unique } \\
\text { peptide } \\
\text { P9 T8 }\end{array}$ & $\begin{array}{c}\text { Biological } \\
\text { process/molecular } \\
\text { function }\end{array}$ \\
\hline 28 & Adenosylhomocysteinase B & 093477 & 48 & 0 & 1 & $\begin{array}{c}\text { one-carbon } \\
\text { metabolic process }\end{array}$ \\
\hline 29 & Egg envelope glycoprotein & Q4VGP0 & 108 & 0 & 1 & Unknown \\
\hline 30 & $\begin{array}{l}\text { Embryonic polyadenylate- } \\
\text { binding protein } \mathrm{B}\end{array}$ & Q6GR16 & 71 & 0 & 1 & mRNA processing \\
\hline 31 & Nucleolin & B7ZR96 & 75 & 0 & 1 & $\begin{array}{l}\text { Nucleic acid } \\
\text { binding }\end{array}$ \\
\hline 32 & $\begin{array}{l}\text { ATP synthase subunit } \\
\text { alpha, mitochondrial }\end{array}$ & P08428 & 59 & 0 & 1 & $\begin{array}{l}\text { ATP biosynthetic } \\
\text { process }\end{array}$ \\
\hline 33 & $\begin{array}{l}\text { O-6-methylguanine-DNA } \\
\text { methyltransferase }\end{array}$ & Q8AVP6 & 35 & 0 & 1 & DNA repair \\
\hline 34 & ribosomal protein S27a & Q6GMC1 & 18 & 0 & 1 & Translation \\
\hline 35 & LOC414450 protein & Q6NTL7 & 13 & 0 & 1 & Unknown \\
\hline 36 & Caveolin & Q8AVS7 & 17 & 0 & 1 & $\begin{array}{l}\text { Various (e.g. } \\
\text { vesicle trafficking, } \\
\text { cholesterol } \\
\text { homeostasis, signal } \\
\text { transduction) }\end{array}$ \\
\hline 37 & PKC-delta2 protein & Q498G7 & 78 & 0 & 1 & signal transduction \\
\hline
\end{tabular}


$1 \mathrm{~A}$

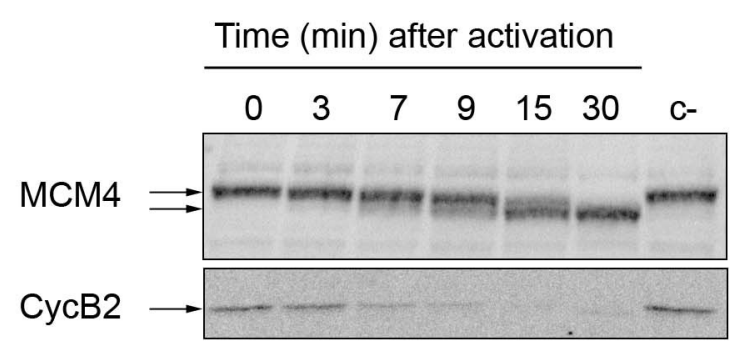

1B

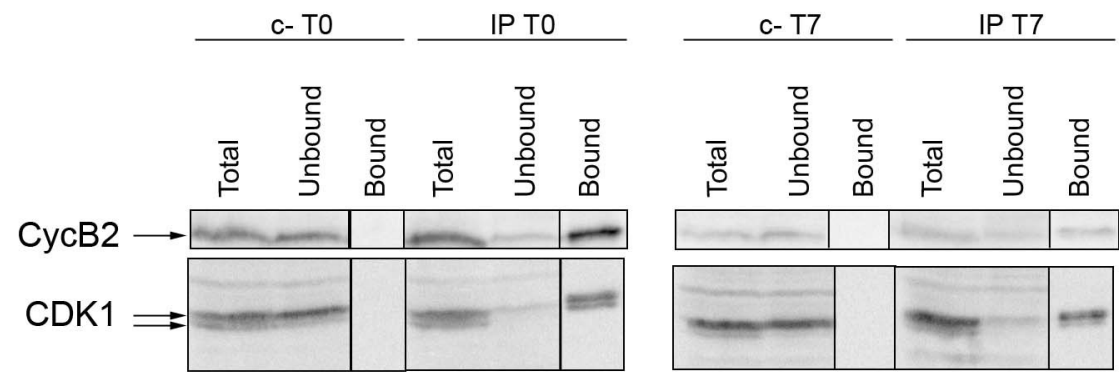

$1 C$

온

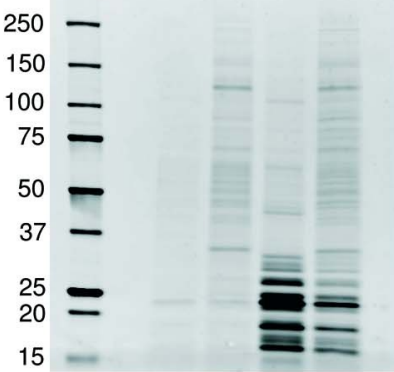

Figure 1 


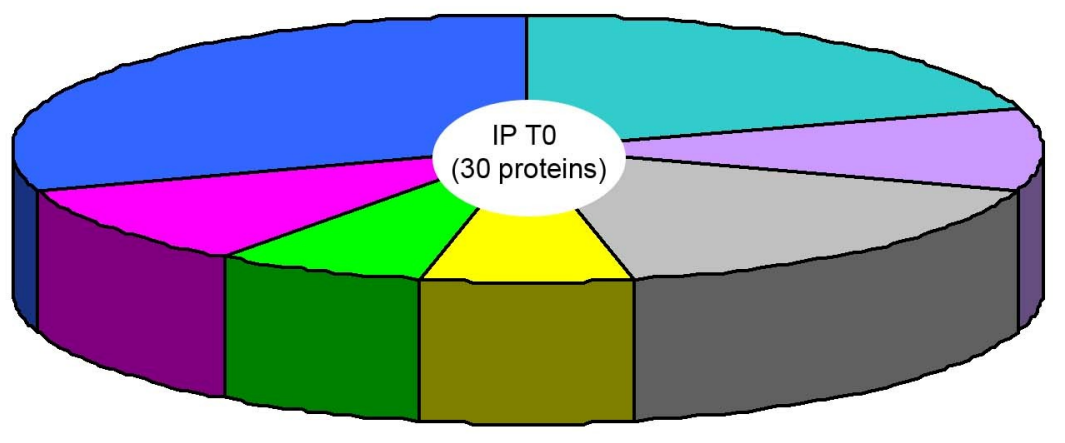

$\square$ Cell cycle/division

$\square$ Metabolism

$\square$ Chaperonin

$\square$ Cytoskeleton / vesicle transport

$\square$ Fertilization

口DNA/RNA metabolism

$\square$ Other

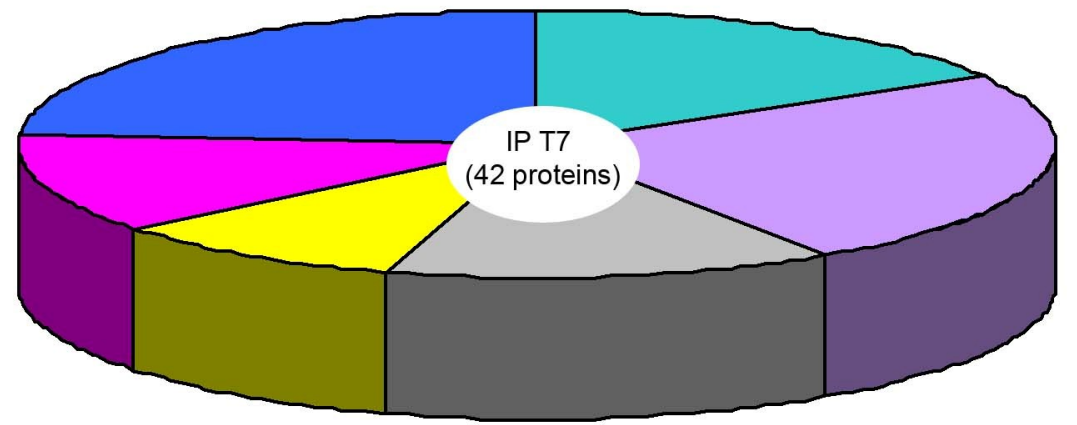

$\square$ Cell cycle/division

$\square$ Metabolism

$\square$ Chaperonin

$\square$ Cytoskeleton / vesicle transport

$\square$ DNA/RNA metabolism

$\square$ Other

Figure 2 
$3 A$

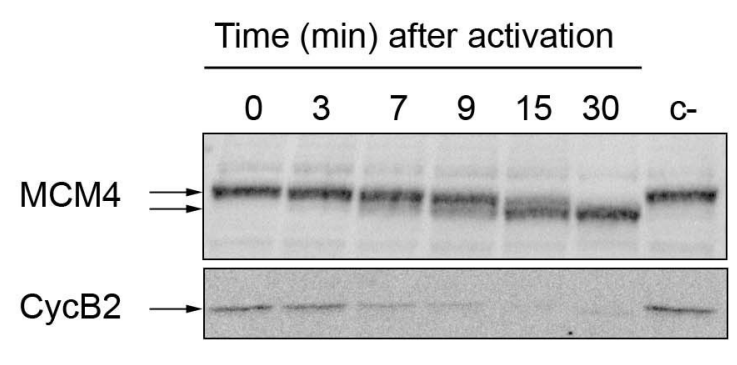

3B

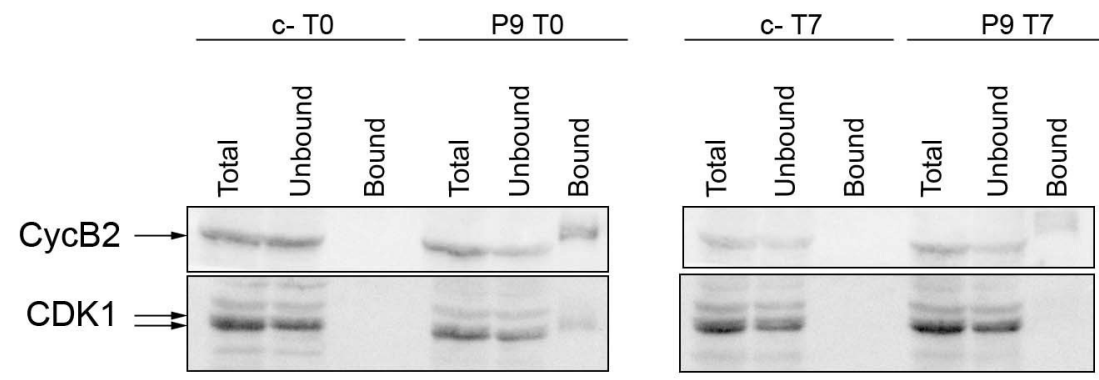

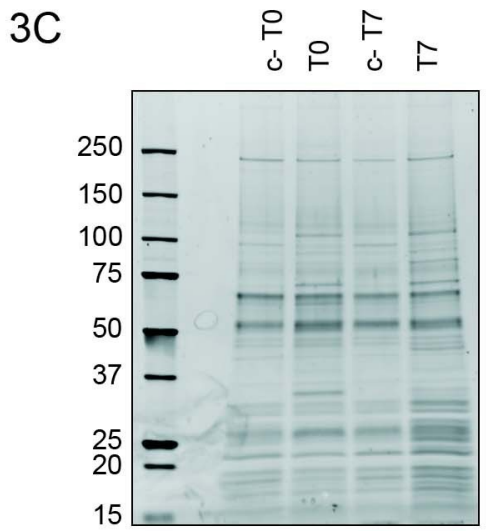

Figure 3 


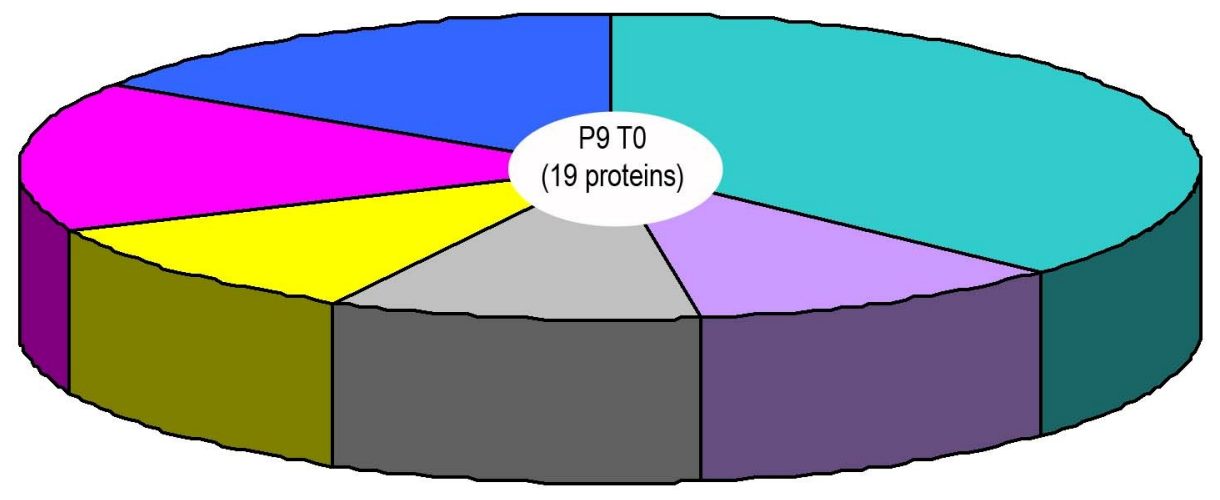

$\square$ Cell cycle/division

$\square$ Metabolism

$\square$ Chaperonin

$\square$ Cytoskeleton / vesicle transport

口DNA/RNA metabolism

$\square$ Other

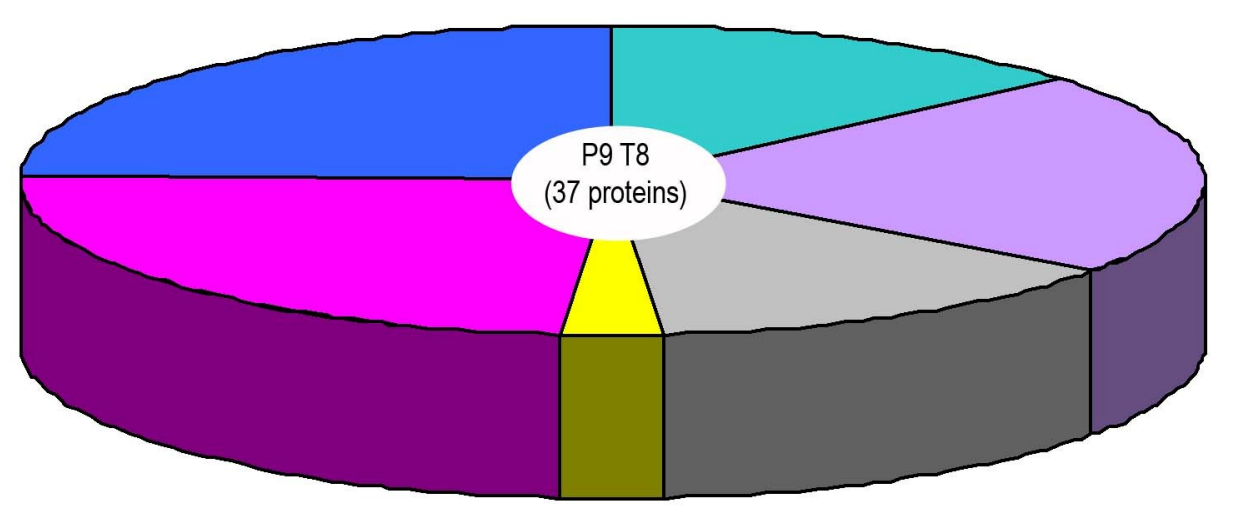

$\square$ Cell cycle/division

$\square$ Metabolism

$\square$ Chaperonin

$\square$ Cytoskeleton / vesicle transport

$\square \mathrm{DNA} / \mathrm{RNA}$ metabolism

$\square$ Other

Figure 4 
A

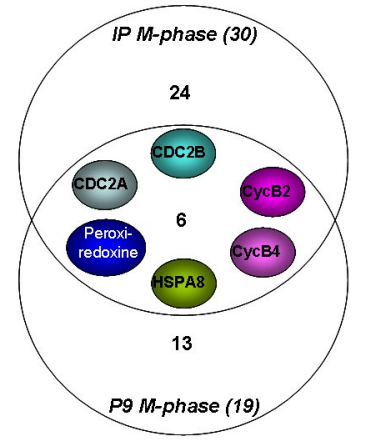

B

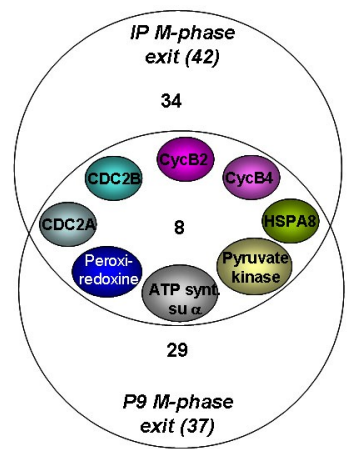

C

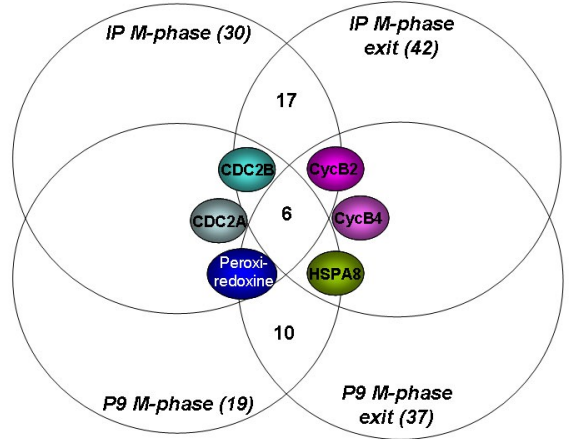

Figure 5 